\title{
RELIGIOUS DIMENSIONS OF MALAYSIA'S WELLBEING INDEXES
}

\author{
Azila Ahmad Sarkawi a, Alias Abdullah ${ }^{\mathrm{b}}$ and Norimah Md. Dali c \\ abc International Islamic University Malaysia, Malaysia \\ Corresponding email: azila@iium.edu.my
}

\begin{abstract}
Amongst the 57 members of the Organisation of the Islamic Conference's (OIC) countries, Malaysia is at number one rating in the Islamicity Index, Islamic Index of Wellbeing and Global Muslim Travel Index studies. The rating gave the impression of the liveability or wellbeing in Malaysia within the Islamic sphere. This recognition prompts the study on the indicators of wellbeing that Malaysia has focused on Islamic dimensions. Consequently, content analysis was done on six selected government documents namely the Malaysian Wellbeing Index, the Malaysian Family Wellbeing Index, the Malaysian Urban-Rural National Indicators Network for Sustainable Development, the Malaysian Shariah Index, the Malaysian Ummah Development Index and the Muslim Religiosity and Personality Indexing. The study found that the first three documents embodied indirect religious dimensions in their wellbeing indexing while the latter three have direct religious dimensions. The incorporation of the religious dimensions into the Malaysia's wellbeing indexing either directly or indirectly shows the relevancy of the religious factor to human wellbeing. Noticeably, the indicators promulgated under each study are organizationally-driven aiming at attaining their specific objectives that invariably led to variations amongst the agencies. Nonetheless, religion has been found to command a significant factor in the wellbeing of Malaysian though different indicators have been used by the six organizations to arrive at this fact.
\end{abstract}

Keywords: Index, Malaysia, Religion, Quality of Life \& Wellbeing.

\section{Introduction}

The Federal Constitution of Malaysia endorsed Islam as the religion of the Federation. This is specifically stated in Article 3(1) however other religions may be practiced in peace and harmony. Indeed, in the drive towards efficient public service delivery, the government commits itself to instill religious principles in its development strategies and public policies. As testimony to the seriousness of the government machinery, the Prime Minister launched the Malaysian Shari'ah Index (MSI) on February 10, 2015 as a Key Performance Index tool to measure the compliance of shari'ah(Islamic law) in its administration. Eight sectors that hinged on Malaysian wellbeing were measured namely law, politics, social, culture, education, economics, health, infrastructure and environment. On the $28^{\text {th }}$ March 2016 , he announced that the overall score of the Shari'ah compliance of these sectors was 75.42 per cent last year. This reflects a scientific measure of the country's achievements from the prism of Islam. In relation to the religious dimension of the wellbeing indicators in Malaysia, several government agencies, like the Federal Town and Country Planning Department (FTCPD), The Economic Planning Unit (EPU), The Institute of Understanding Islam (popularly referred to as IKIM) and The National Family and Population Development Board (in Malay, LPPKN) had, to a certain extent, shown that the initiative to integrate the Islamic factorhad in fact begun earlier. However, unlike the MSI, these studies were not explicitly streamlined according to the Maqasid al-shariah categorization. For the MSI, the five Maqasid categories i.e. faith, self, intellect, lineage and wealth were based upon as the main indicators of human wellbeing. The Muslim Religiosity and Personality Indexing (MRPI) developed by Universiti Putra Malaysia (UPM) in 2004 which focused on the religious component could also be incorporated to beef up the Malaysian wellbeing 
indicators undertaken by the other agencies.

Some emerging questions that need to be addressed include why is religion important?; What is its relationship with human wellbeing?; How has it been measured?. The paper henceforth attempts to answer these questions by looking into the existence of religious dimension in each kind of index, the degree of its attachment to the human wellbeing based on the result of the survey and the religious-related indicators.

Thus, the sequence of this paper is structured under five sections starting with the introductory remarkson the state of the wellbeing indexing studies in Malaysia, followed by a section on literature review of each wellbeing index explaining their indicators in detail. Section three describes the methodology adopted in this study followed by the analysis and discussion in section four. Finally section five concludes the discussion.

\section{Malaysian Wellbeing Indexes}

Available published materials suggest that in Malaysia there are several indexes related to the wellbeing studies. They are all government-led initiatives. Based on the authors' observations, there are six remarkable ones with their respective agencies as listed in Table 1.

Table 1: Wellbeing related indexes in Malaysia and their governing agencies

\begin{tabular}{|l|l|l|}
\hline No & \multicolumn{1}{|c|}{ Well being related indexes } & \multicolumn{1}{c|}{ Government agencies } \\
\hline 1 & Malaysian Wellbeing Index (MWI) & Economic Planning Unit (EPU) \\
\hline 2 & Malaysian Family Wellbeing Index(MFWI) & $\begin{array}{l}\text { National Family and Population } \\
\text { Development Board (in Malay, LPPKN) }\end{array}$ \\
\hline 3 & $\begin{array}{l}\text { Malaysian Urban-Rural National Indicators } \\
\text { Network for } \begin{array}{l}\text { Sustainable } \\
\text { Development(MURNInets) }\end{array}\end{array}$ & $\begin{array}{l}\text { Federal Town and Country Planning } \\
\text { Department (in Malay, JPBD) }\end{array}$ \\
\hline 4 & $\begin{array}{l}\text { Malaysian ShariahIndex(MSI) } \\
5\end{array}$ & $\begin{array}{l}\text { Malaysian Ummah Development Index } \\
\text { MUDI) Pepartment of Islamic Development } \\
\text { Malaysia (in Malay, JAKIM) }\end{array}$ \\
\hline 6 & $\begin{array}{l}\text { Institute of Understanding Islam (in } \\
\text { Maslim, Religiosity and Personality } \\
\text { Indexing(MRPI) }\end{array}$ & $\begin{array}{l}\text { Institute for Community and Peace } \\
\text { Studies (in Malay, PEKKA, UPM) }\end{array}$ \\
\hline
\end{tabular}

It now becomes essential to describe each one of the above indexes in detail as follows:

\section{Malaysian Wellbeing Index, Economic Planning Unit (EPU)}

The Malaysian Wellbeing Index (MWI) documented in 2013 under the purview of EPU is a continuation of the Malaysian Quality of Life Index (MQLI)1999, 2002, 2004 and 2011 series. However, as Malaysia progresses towards a high-income economy, the government felt that there is a need to further strengthen the indicators of the MQLI to be more comprehensive. Hence, the MQLI was enhanced and reformulated into the MWI comprising 2 sub composites, 14 components and 68 indicators. The objectives of MWI are, firstly, to complement the measurement of economic development which is traditionally based on income per capita; secondly to measure impacts of socio-economic policies on the quality of life and wellbeing of the people; and lastly to identify socio-economic issues in order to formulate appropriate policies and strategies. The government is striving to deliver a wellbalanced socio-economic advancement to the country and its population by 2020 . 


\section{Malaysian Family Wellbeing Index, National Family and Population Development Board}

The Malaysian Family Wellbeing Index (MFWI) is an initiative of the National Family and Population Development Board, Malaysia in 2011. It was developed to measure the state of wellbeing of families, as well as for use in new social policy formulation, planning for implementation of future research, the development of new programmes and services, and expansion of programmes under the Board. The development of the MFWI was focused on subjective wellbeing in which all respondents were asked to give assessments on the seven dimensions and 24 indicators related to their family. The MFWI used the value of 10 as the maximum score. Because of its usefulness, the authority is now working on the second MFWI study via surveys in 2016.

\section{Malaysian Urban-Rural National Indicators Network for Sustainable Development, Federal Town and Country Planning Department}

The Federal Town and Country Planning Department (FTCPD) had started to formulate the Malaysian Urban Rural Indicators Network (MURNInet) in 1998. The MURNInet is an innovative system that determines the sustainability level of an urban area by using a set of urban indicators. It enables the tracking of the sustainability status of an urban area whether it has increased, reduced or static. In MURNInet - A sustainable urban area is defined as an area that is capable of sustaining its social, economic and physical development achievements whilst maintaining excellence in culture and environment. MURNInet is applicable to all the 154 Local Authorities in Malaysia since their role is crucial in creating peoples' wellbeing. Moreover, to keep tabs with emerging issues of urbanization and sustainability, the MURNInet had to be revised and in 2012the FTCPD produced the Malaysian Urban-Rural National Indicators Network on Sustainable Development (MURNInets) which is streamlined into six dimensions, 21 themes and 36 indicators.

\section{Malaysian Shari'ah Index, Department of Islamic Development Malaysia}

Malaysian Shari'ah Index(MSI) was prepared by the Department of Islamic Development Malaysia. This index is said tobe a scientific evaluating method that serves two functions. Firstly, it evaluates the seriousness of the government's efforts on a yearly basis in meeting the Islamic standards when implementing government policies and programs. Secondly, it identifies areas for improvement that need the government's attention. In addition, it also serves as a benchmark to determine if the country is fulfilling the objectives of Islamic principles (Maqasidal-Shariah), and objectively gauging Malaysia's commitment in achieving the five aspects of the Maqasid al-Shariah. The MSI is one of the development indexes based on thefive main elements (daruriyyat al-khams) of the Maqasid al-shariah (Objectives of Islamic Law). This move proved Malaysia's commitment in developing its policies and national administrative and development programs that are shariah compliant via the eight important sectors i.e. jurisprudence, politics, economics, education, health, culture, infrastructure and environment and social.

\section{Malaysian Ummah Development Index, Institute of Islamic Understanding Malaysia}

The Institute of Islamic Understanding Malaysia (IKIM) has proposed a Malaysian Ummah Development Index (MUDI)in 2014to indicate the achievement of the Muslim population in their wellbeing. MUDI emphasised the balance between the three types of wellbeing i.e. economic, social and spiritual via its three dimensions and 21 indicators.MUDI is an extension to the economic development and social development indicators devised in the MWI, 2013. It is developed to integrate the physical and spiritual development aspects. This index would help provide an indicator of development for the Muslims which inculcate the 
spiritual elements. This is because Muslim societies in Malaysia in particular require several indicators that would be able to show whether those social and economic development achieved fulfils the comprehensive requirements as set forth by the teachings of Islam.

\section{Muslim Religiosity-Personality Indexing, University Putra Malaysia}

The Muslim Religiosity-Personality Indexing (MRPI) has been developed in 2004to measure components of Muslim religiosity and to understand it from the perspective of adherence, orientation, attitude and their relation to personality and its manifestations in everyday behaviours. The MRPI measurement model was developed as the basis to assess three aspects of Islam, Iman and Ihsan in relation to the Islamic Worldview and Religious Personality. Iman includes individual knowledge and perceptions towards the six articles of Iman while Ihsan includes individual attitudes and behaviours that emerge from his/her values. Hence, these are manifested in their practice of the five tenets of Islam.Ihsan means the spiritual excellence or actualization of the highest order. The collective attainment of ihsan at the community level protects the individuals, communities and the environment.

Having explained all the six documents, there emerge two sets of Islamic wellbeing indicators either the dimension is directly or indirectly mentioned. Thus, the study proceeded with an analysis on their respective indicators using a content analysis method.

\section{Method}

The aim of the study reported herein is to deduce the religious dimension from the contemporary indexes of peoples' wellbeingin Malaysia. This deduction is made to evaluate the degree of its existence to strategise steps for improvement. The study employed a desk research approachto identify studies of the peoples' wellbeingand six documents had been recognized as relevant. Having identified the documents, their indicators were critically reviewed using the content analysis method which finally leads to the study's findings of the religious dimensions in them.

\subsection{Analysis and discussion}

The aim of the study is to derive the religious dimension in each wellbeing index of Malaysia. Thus a critical review of its indicators was conducted individually. MWI comprises of2 sub composites, 14 components and 68 indicators as shown in Table 2.

Table 2: Two sub composites, fourteen components and sixty-eight indicators of theMWI

\begin{tabular}{|c|c|c|c|}
\hline \multicolumn{4}{|c|}{ Malaysian Wellbeing Index, Economic Planning Unit (EPU) } \\
\hline \multicolumn{4}{|c|}{ 1. Economic wellbeing } \\
\hline \multirow{6}{*}{$\begin{array}{l}\text { i. Transport } \\
\text {-Road development index } \\
\text {-Private motorcars \& } \\
\text { motorcycles (per 10,000 } \\
\text { population) } \\
\text {-Road length per capita (km) } \\
\text {-Rail ridership (million) }\end{array}$} & \multicolumn{2}{|c|}{ ii. Working life } & \\
\hline & \multicolumn{2}{|c|}{-Trade disputes (-) } & -Real per capita income \\
\hline & \multicolumn{2}{|c|}{-Man-days lost due to } & $(\mathrm{GNP})(\mathrm{RM})$ \\
\hline & \multirow{2}{*}{\multicolumn{2}{|c|}{$\begin{array}{l}\text { industrial action ('ooo)(-) } \\
\text {-Industrial accidents (-) }\end{array}$}} & -Gini coefficient based on \\
\hline & & & aisposabie income (-) \\
\hline & & $\operatorname{ars}(-)$ & \\
\hline \multirow{6}{*}{\multicolumn{2}{|c|}{$\begin{array}{l}\text { iv. Education } \\
\text {-Pre-school participation rate } \\
\text {-Primary school participation rate } \\
\text {-Secondary school participation rate } \\
\text {-Tertiary participation rate } \\
\text {-Literacy rate }\end{array}$}} & \multicolumn{2}{|c|}{ v. Communications } \\
\hline & & -Fixed. & \& mobile telephone line \\
\hline & & & tions (per 10,000 population) \\
\hline & & -Intern & $t$ subscriber (per 10,000 \\
\hline & & & \\
\hline & & & r of hotspot locations \\
\hline
\end{tabular}


$-\%$ of graduate teachers in primary school

-\% of graduate teachers in secondary school

-National average grade UPSR

-National average grade SPM

-Number of lecturers with $\mathrm{PhD}$

-Primary education survival rate

-Secondary education survival rate

\section{Social wellbeing}

\begin{tabular}{|c|c|c|}
\hline $\begin{array}{l}\text { i. Housing } \\
\text {-\% of low-cost housing units } \\
\text { to bottom } 40 \\
-\% \text { of households with } \\
\text { treated water } \\
-\% \text { of households with } \\
\text { electricity } \\
-\% \text { of households with } \\
\text { garbage collection services } \\
\text {-Crowdedness (no. of } \\
\text { persons per room)(-) }\end{array}$ & $\begin{array}{l}\text { ii. Leisure } \\
\text {-No. of households with paid } \\
\text { TV subscription (per 10,00o } \\
\text { population) } \\
\text {-Domestic hotel guests (per } \\
\text { 10,ooo population) } \\
\text {-Recreational parks visitors } \\
\text { (per 'ooo population) } \\
\text {-Cinema goers (per 10,00o } \\
\text { population }\end{array}$ & $\begin{array}{l}\text { iii. Governance } \\
\text {-\% of corruption cases } \\
\text { prosecuted } \\
\text {-No. of e-payment } \\
\text { transactions (million) } \\
\text {-\% of cases solved by Public } \\
\text { Complaint Bureau } \\
\text {-\% of e-filing users }\end{array}$ \\
\hline $\begin{array}{l}\text { iv. Public safety } \\
\text {-Crime rate (per 'ooo } \\
\text { population) } \\
\text {-Road accidents (per 'ooo } \\
\text { vehicles) }\end{array}$ & $\begin{array}{l}\text { v. Social participation } \\
\text {-\% of registered voters (per } \\
\text { population aged } 21 \text { years and } \\
\text { above } \\
\text {-No. of registered non-profit } \\
\text { organizations (per 10,000 } \\
\text { population) } \\
\text {-No. of registered residents' } \\
\text { associations } \\
\text {-Membership in RELA and } \\
\text { RakanCop (per 10,000 } \\
\text { population }\end{array}$ & 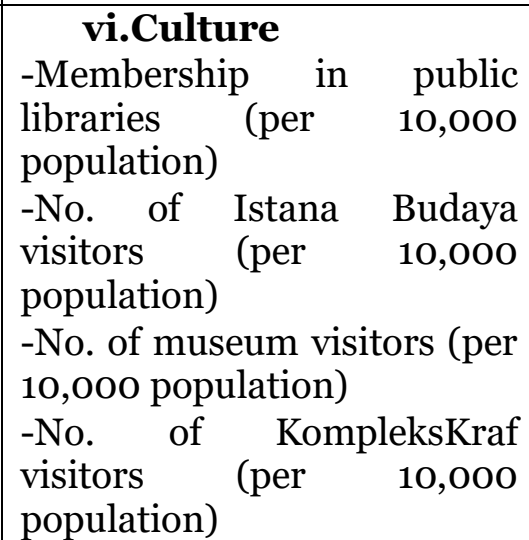 \\
\hline $\begin{array}{l}\text { vii. Health } \\
\text {-Life expectancy at birth } \\
\text {-Non-communicable disease } \\
\text { cases (per 10,000 } \\
\text { population) } \\
\text {-Infant mortality rate (per } \\
\text { 1,ooo live births) } \\
\text {-Maternal mortality rate (per } \\
\text { 100,ooo live births) } \\
\text {-No. of beds in hospitals (per } \\
\text { 10,ooo population) } \\
\text {-Doctor to population ratio } \\
\text {-Hospital waiting time for } \\
\text { outpatients (minute) }\end{array}$ & $\begin{array}{l}\text { viii. Environment } \\
\text {-Air quality (\% of station } \\
\text { with API <50) } \\
\text {-Water quality (\% of clean } \\
\text { river monitored) } \\
\text {-\% of forested land } \\
\text {-Quantity of scheduled waste } \\
\text { generated } \\
\text { (tones/year)/population } \\
\text {-Maximum mean } \\
\text { temperature in Celsius }\end{array}$ & $\begin{array}{l}\text { ix. Family } \\
\text {-Divorce rate (\% of } \\
\text { population aged } 18 \text { and } \\
\text { above) } \\
\text {-Domestic violence cases (per } \\
\text { 10,ooo population) } \\
\text {-Juvenile crimes (\% of } \\
\text { population aged 10-18) } \\
\text {-Mean monthly household } \\
\text { income (RM) } \\
\text {-Household debt per capita } \\
\text { (RM) } \\
\text {-Dependency ratio }\end{array}$ \\
\hline
\end{tabular}

-Number of domain name (per 10,000 population)

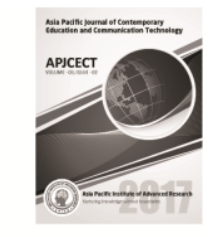


libraries membership and Istana Budaya, Museum and KompleksKraf visitors. In the 2014 preliminary survey result, it stood at number 9 out of 14 dimensions under study.In contrast, the Malaysian Family Wellbeing Index which consists of 7 dimensions and 24 indicators, incorporatedthe religious and spirituality indicators specifically into its dimensions. This can be seen clearly in Table 3 below especially in the sixth dimension.

Table 3: Malaysian Family Wellbeing Index and its 7 dimensions and 24 indicators

\begin{tabular}{|c|c|c|c|c|c|}
\hline \multicolumn{6}{|c|}{$\begin{array}{lcc}\text { Malaysian } & \text { Family } \\
\text { Development Board } & \text { Wellbeing Index, }\end{array}$} \\
\hline \multicolumn{2}{|c|}{$\begin{array}{l}\text { 1.Family Relationships } \\
\text {-Parental involvement } \\
\text {-Family resilience } \\
\text {-Family functioning } \\
\text {-Time with family } \\
\text {-Work-family balance } \\
\text {-Husband/wife relationship } \\
\text {-Parental relationship }\end{array}$} & \multicolumn{2}{|c|}{\begin{tabular}{|l|} 
2.Family Economy \\
-Family living standards \\
-Family economic situation \\
-Future savings \\
-Debt burden
\end{tabular}} & \multicolumn{2}{|c|}{$\begin{array}{l}\text { 3.Family Health } \\
\text {-Family health practice } \\
\text {-Family health level } \\
\text {-Stress management }\end{array}$} \\
\hline $\begin{array}{l}\text { 4.Family Safety } \\
\text {-Emergency } \\
\text { response knowledge } \\
\text {-Safety at home } \\
\text {-Family safety }\end{array}$ & $\begin{array}{l}\text { 5.Fai } \\
\text { Com } \\
\text {-Com } \\
\text {-Com } \\
\text {-Com }\end{array}$ & $\begin{array}{l}\text { ily } \\
\text { unity } \\
\text { unity cooperation } \\
\text { unity relationship } \\
\text { unity involvement }\end{array}$ & $\begin{array}{r}\mathbf{6 . 1} \\
\mathbf{R e} \\
\mathbf{S p} \\
\text {-Role o } \\
\text {-Spiritı }\end{array}$ & $\begin{array}{l}\text { ily \& } \\
\text { on/ } \\
\text { uality } \\
\text { igion }\end{array}$ & $\begin{array}{l}\text { 7.Housing \& } \\
\text { Environment } \\
\text {-Basic amenities } \\
\text {-Pollution levels }\end{array}$ \\
\hline
\end{tabular}

Source: Malaysian Family Wellbeing Index Report (2011), LPPKN

Under this dimension, two questions were asked i.e. whether religion plays an important role in the everyday life of a family andwhetherthe extent of satisfaction within the family is due to their religious and spiritual practices. Interestingly, this dimension scored the highest at 8.25 while the Family Economy dimension recorded the lowest score at 6.90 only. Moving onto the MURNInets which constitutes 6 dimensions, 21 themes and 36 indicators (see Table 4), there is no specific indicator for religious dimension except in its Happiness Index.

Table 4: MURNInets' 6 dimensions, 21 themes and 36 indicators

\begin{tabular}{|c|c|c|}
\hline \multicolumn{3}{|c|}{$\begin{array}{l}\text { Malaysian Urban-RuralNational Indicators Network on } \text { Sustainable } \\
\text { Development, FTCPD }\end{array}$} \\
\hline \multicolumn{3}{|c|}{ 1.Competitive Economy } \\
\hline $\begin{array}{l}\text { i. Economic growth } \\
\text {-Employment growth rate }\end{array}$ & $\begin{array}{l}\text { ii.Poverty } \\
\text {-Urban poverty rate } \\
\text {-Poverty rate }\end{array}$ & $\begin{array}{l}\text { iii.Private investment } \\
\text {-Growth rate of private } \\
\text { investment }\end{array}$ \\
\hline \multicolumn{3}{|c|}{ 2.Sustainable Environmental Quality } \\
\hline $\begin{array}{l}\text { i.Environmental } \\
\text { quality } \\
\text {-Cleanliness level of the } \\
\text { river } \\
\text {-Air quality conditions }\end{array}$ & $\begin{array}{l}\text { ii.Risk } \\
\text { management } \\
\text {-\% of population living in } \\
\text { flood prone area }\end{array}$ & $\begin{array}{l}\text { iii.Environmental } \\
\text { management } \\
\text {-\% of per capita solid waste } \\
\text { generation } \\
\text {-Total programs/ } \\
\text { environmental campaigns } \\
\text { carried out in local } \\
\text { authority area }\end{array}$ \\
\hline \multicolumn{3}{|c|}{ 3.Sustainable Community } \\
\hline $\begin{array}{l}\text { i.Housing } \\
-\% \text { of quality affordable }\end{array}$ & $\begin{array}{l}\text { ii.Community facilities } \\
\text { and recreations }\end{array}$ & $\begin{array}{l}\text { iii.Quality of life } \\
\text {-Ratio of cases relating to }\end{array}$ \\
\hline
\end{tabular}




\begin{tabular}{|c|c|c|c|}
\hline housing units & \multicolumn{2}{|c|}{$\begin{array}{l}-\% \text { residential coverage } \\
\text { within } 400 \text { meters of } \\
\text { community facilities }\end{array}$} & $\begin{array}{l}\text { public nuisance complaints } \\
\text { per 10,ooo population } \\
\text {-Ratio of cases of water and } \\
\text { water borne diseases per } \\
\text { 10,000 population } \\
\text {-\% of Grade A food } \\
\text { premises } \\
\text {-\% of Grade A public toilets } \\
\text {-Happiness index }\end{array}$ \\
\hline \multicolumn{2}{|c|}{$\begin{array}{l}\text { iv.Safety } \\
\text {-Ratio of index crimes per 10,000 population }\end{array}$} & \multicolumn{2}{|c|}{$\begin{array}{l}\text { v.Demography } \\
\text {-Dependency ratio }\end{array}$} \\
\hline \multicolumn{4}{|c|}{ 4.Optimum Use of Land and Natural Resources } \\
\hline $\begin{array}{l}\text { i.Change of land use } \\
\text {-Rate of change in land use } \\
\text { from non-built up to built } \\
\text { up area }\end{array}$ & \multicolumn{2}{|c|}{\begin{tabular}{|l}
\multicolumn{1}{|c|}{$\begin{array}{c}\text { ii.Municipal } \\
\text { development }\end{array}$} \\
-Urbanisation rate \\
-Ratio of public open space \\
per 10,ooo population \\
-Unsold residential \\
property
\end{tabular}} & $\begin{array}{l}\text { iii.Heritage } \\
\text { conservation, } \\
\text { agriculture } \\
\text { tourism } \\
\text {-\% of change in the forest } \\
\text { area } \\
\text {-Number of tourism } \\
\text { attractions and recreational } \\
\text { centers }\end{array}$ \\
\hline \multicolumn{4}{|c|}{ 5.Efficient Transportation and Infrastructure } \\
\hline $\begin{array}{l}\text { i.Utilities efficiency } \\
\text {-Volume of domestic water } \\
\text { per capita } \\
\text {-Total electricity consumptic } \\
\text { capita }\end{array}$ & $\begin{array}{l}\text { consumption } \\
\text { on }(\mathrm{KW}) \text { per }\end{array}$ & \multicolumn{2}{|c|}{$\begin{array}{l}\text { ii.Solid waste management } \\
\text {-\% of total waste recycled } \\
\text {-\% of domestic solid waste collection } \\
\text { schedule }\end{array}$} \\
\hline \multicolumn{2}{|c|}{$\begin{array}{l}\text { iii.Transportation } \\
\text {-Number of integrated public transport } \\
\text { terminal stations }\end{array}$} & \multicolumn{2}{|c|}{$\begin{array}{l}\text { iv.Sewerage management } \\
\text {-\% of homes with centralised sewerage } \\
\text { services }\end{array}$} \\
\hline \multicolumn{4}{|l|}{ 6.Effective Governance } \\
\hline $\begin{array}{l}\text { i.Delivery system } \\
\text {-Residents' } \\
\text { level on Latisfaction } \\
\text { services } \\
\text {-Number of community } \\
\text { programs implemented by } \\
\text { local authority }\end{array}$ & $\begin{array}{l}\text { ii.Institu } \\
\text { improve } \\
\text {-\% of loce } \\
\text { revenue } \\
\text { performance } \\
\text {-\% of total } \\
\text { expenditure } \\
\text { the overall lo } \\
\text { spending. }\end{array}$ & $\begin{array}{l}\text { Itional } \\
\text { ment } \\
\text { al authority } \\
\text { collection } \\
\text { maintenance } \\
\text { compared to } \\
\text { cal authority }\end{array}$ & $\begin{array}{l}\text { iii.Enforcement } \\
\text { and monitoring } \\
\text {-\% of approved planning } \\
\text { applications that comply to } \\
\text { the development plans } \\
\text {-Number of enforcement } \\
\text { operations executed } \\
\text { according toschedule by } \\
\text { Local Planning Authority. }\end{array}$ \\
\hline
\end{tabular}

Source: Malaysian Urban-Rural National Indicators Network on Sustainable Development Manual (2013), FTCPD

The Happiness Index 2013 is a study under the dimension of Sustainable Community and Quality of Life theme of the MURNInets. The study is a primary data collection - survey carried out jointly between FTCPD and local authorities and the residents. A total of 13 questions were asked regarding stress level, health, family and partner relationship, job 
satisfaction, monthly income, neighbour relationship, safety, adequacies of public facilities, environment quality and political representation. Of the 13 questions, there was one question regarding the significance of religion in human life when the respondents were asked whether they believed that spirituality could bring joy and happiness in their lives. Out of the 5 Likert scale, residents' responsesin the Barometer analysis of the Happiness Index are consistently at 5.00 (Happier) scales. This shows that Happiness, in especially the religiosity aspect, is a pre-requisite in generating sustainable communities and urban development.

Notwithstanding, by virtue of their names and objectives, the following three indexes portray a more significant content of religious dimensionin contrary to the aforesaid three wellbeing indexes. This is evident through their indicators shown in Table 5.

Table 5: The MUDI, MRPI and MSI's indicators

\begin{tabular}{|c|c|c|c|}
\hline 1 & \multicolumn{3}{|c|}{ Malaysian Ummah Development Index(MUDI), IKIM } \\
\hline & $\begin{array}{l}\text { 1.Economic } \\
\text { Development Index } \\
\text {-Average monthly } \\
\text { household income } \\
\text {-Gini coefficient } \\
\text {-Rate of unemployment } \\
\text {-Rate of poverty } \\
\text {-Ownership of share capital } \\
\text { in limited companies (\%) } \\
\text {-Ratio of deposit of Islamic } \\
\text { banking system and non- } \\
\text { financial institutions to } \\
\text { total banking industry (\%) } \\
\text {-Per capita zakat }\end{array}$ & $\begin{array}{l}\text { 2.Social Development } \\
\text { Index } \\
\text {-Rate of enrolment in } \\
\text { learning institutions } \\
\text {-Rate of graduate per } \\
\text { 10,ooo population } \\
\text {-Doctors per 10,0oo } \\
\text { population } \\
\text {-Life expectancy rate } \\
\text {-Ratio of marriages per } \\
\text { 10,ooo population } \\
\text {-Ratio of divorces per } \\
\text { 10,ooo population } \\
\text {-Average number of }\end{array}$ & $\begin{array}{l}\text { 3.Spiritual } \\
\text { Development Index } \\
\text {-Number of mosques per } \\
\text { 10,ooo population } \\
\text {-Number ofZakat payers } \\
\text { per 10,0oo population } \\
\text {-Number of Depositors of } \\
\text { Tabung Haji per 10,0oo } \\
\text { population } \\
\text {-Number of registered } \\
\text { Muslim professionals per } \\
\text { 10,ooo population } \\
\text {-Number of prisoners per } \\
\text { 10,ooo population } \\
\text {-Number of crimes of } \\
\text { integrity per 10,ooo } \\
\text { population } \\
\text {-Number of drug addicts } \\
\text { per 10,0oo population }\end{array}$ \\
\hline & \multicolumn{3}{|c|}{ Malaysian Shari'ah Index(MSI), JAKIM } \\
\hline & \begin{tabular}{|l|l|} 
Politic & Econo \\
\end{tabular} & \begin{tabular}{|l|l|} 
ny & Social \\
\end{tabular} & \\
\hline & Educa & Health & \begin{tabular}{l|l} 
Infrastructure and \\
Environment
\end{tabular} \\
\hline & \multicolumn{3}{|c|}{ Muslim Religiosity and Personality Indexing (MRPI), UPM } \\
\hline & Islamic worldview ( 51 items) & \multicolumn{2}{|c|}{ Religious personality (100 items) } \\
\hline
\end{tabular}

Source: MUDI Report (2014), MRPI (2006), MSI (2015)

Nevertheless, the indicators are skewed towards the current aim and objectives of its specific organization, thus opening rooms for improvement. MUDI in particular could be improved by basing its indicators on the five essentials of Maqasid al-shariah namely faith, self, intellect, posterity and property to provide more comprehensive and justified evaluation. Though the MSI is already based on these five essentials of Maqasid al-shariah, it is a study on the government policies whether or not they are shariah compliant. If it is affirmative, the government wants to see the level of achievement and if not what are the steps to improve. This effort is commendable since it elicits further actions to scrutinize each sector of thestudy in the quest for people's wellbeing. In consequence, MRPI serves a tool to assess 
the first essential of the Maqasid al-shariah that is the religiosity dimensions. MRPI worked this outthrough its 51 items under theIslamic Worldview values and 100 items under the Religious Personality values. However, the challenge remains for the items to be able to reflect each of theIslamic basic principlesof Islam, Iman and Ihsan forcefully.

In summary, the religious dimensions in the existing Malaysia indexes of wellbeing appear either directly or indirectly that could be traced by virtue of their names. The earlier batch i.e. MWI, MFWI and MURNInets considered the religious dimension in a rathernon-specific and superficial way while the second batch comprising MUDI, MSI and MRPI dwelled with them quite directly and specifically. All three latter indexes portray Islamic-oriented indicators. On the contrary, the fallacy of the MWI is quite obvious when the indicators used did not reflect the cultural component as defined by the document. MFWI and MURNInets, though attempted to include religious dimensions but gave inadequate emphasis on them.

\section{Conclusion}

In Islam, religion contributes to human wellbeing tremendously by way of spiritual dependency to the Creator, Allah SWT that is constantly manifested in religious practices, behaviours and way of life. This relationship is evident when the three Islamic-oriented indexes i.e. MUDI, MSI and MRPI are strong in their direct Islamic content (thoughwithin their limitations aforesaid highlighted). However, in contrast to the conventionalworldview human wellbeing indexes, the religious content could be either indirect or superficial like those of theMWI, MFWI and MURNInets. Hence, for the latter, there are rooms for improvement within the perspectives of Maqasid al-Shariahwhere indicators pertaining to the protection of faith, life, intellect, lineage and wealthcould be embedded to makethe measurement of human wellbeing indicators more comprehensive and justified. Finally, the religious dimension is found important in promoting liveability, quality of life and human wellbeing at all levels i.e. from individual, family, community and cities. This study found that religiosity could be measured via specific measurement tool like MRPI and should be widely applied especially in Malaysia where Islam is proclaimed as the official religion and majority of its population are Muslims.

\section{Acknowledgements}

The research for this paper was financially supported by the MyRA Incentive Research Grant Scheme (MIRGS) 2013 (Project ID: MIRGS 13-02-001-0005) Ministry of Education, Malaysia. We would like to thank the Government of Malaysia particularly the Ministry of Education and International Islamic University Malaysia in accomplishing this research. 


\section{References}

i. Department of Islamic Development Malaysia (JAKIM), 2015. SoalJawabKajianIndeksSyariah Malaysia, Utusan Malaysia. [Online] Available at: http://www.ikim.gov.my/index.php/en/ [Accessed 11 January 2015].

ii. Department of Islamic Development Malaysia, 2015. JAKIM. [Online] Available at: http://www.islam.gov.my/en [Accessed 11 January 2015].

iii. Hamid, A. S. A., 2007. "Indeks Pembangunan Ummah - Kes Malaysia" in Malaysia SebagaiSebuah Negara Islam, Kuala Lumpur: Institute of Islamic Understanding Malaysia (IKIM).

iv. Hsieh, H.-F. \& Shannon, S. E., 2005. Qualitative Health Research. Qualitative Health Research, 15(9), pp. 1277-1288.

v. Institute for Community and Peace Studies (PEKKA), 2007. "Muslim Religiosity and Personal Indexing-Implications for Nation Building. 2nd ed. Putra: Universiti Putra Malaysia (UPM).

vi. Kamali, M., 2008. Maqasid al-Shariah made simple. Malaysia: International Institute of Advanced Islamic Studies (IAIS).

vii. Kondracki, N. \& Wellman, N., 2002. Content analysis: Review of methods and their applications in nutrition education. Journal of Nutrition Education and Behavior, Volume 24, pp. 224-230.

viii. Malaysian Urban Rural National Indicators Network (MURNI), 2008. Federal Department of Town and Country Planning, Peninsular Malaysia, Ministry of Housing and Local Government.

Available at: http://murninet.townplan.gov.my/

[Online]

ix. Malaysian Urban Rural National Indicators Network on Sustainable Development (MURNInets), 2012. MURNInets. [Online].

x. MohdShukriHanapi, 2015. The Islamic-Based Development Index (Ibd-I) Worldview: A Case Of The Malaysian Syariah Index (MSI). [Online]

Available at: http://apiar.org.au/wp-content/uploads/2015/o8/APCAR_BRR7431.pdf [Accessed 8 August 2015].

xi. MQLI, 1999. the Economic Planning Unit (EPU). [Online] Available at: http://www.epu.gov.my/

xii. MUDI, n.d. The Institute of Islamic Understanding. [Online] Available at: http://www.ikim.gov.my/index.php/en/

xiii. MWI, 2013. Unit Perancang Ekonomi (UPE). [Online] Available at: http://www.epu.gov.my

xiv. Nor, F. M., 2014. PelaksanaanIndeks Pembangunan Ummah (MUDI) :KeperluanDalamKonteksMaqasidSyariah, Proceeding of the International Conference on Masjid, Zakat and Waqf (IMAF). Kuala Lumpur, Malaysia, PelaksanaanIndeks Pembangunan Ummah (MUDI).

xv. NST, 2016. Malaysia-Syria Compliance Score. [Online]

Available at: http://www.nst.com.my/news/2016/03/135638/index-puts-malaysias-syariahcompliance-score-7542-c [Accessed 3 March 2016].

xvi. Omar et.al, 2014. The Trend Analysis of Islamization in Malaysia Using Islamization Index as Indicator. Asian Economic and Financial Review, 4(10), pp. 1298-1313.

xvii. Sarji, A. A., 2005. Indicators of development of the Muslim Ummah in Malaysia. The encyclopedia of Malaysia: Religions and beliefs. 
xviii. The Malaymailonline, n.d. Malaysia rates itself very good in inaugural Shariah index. [Online] Available at: http://www.themalaymailonline.com/malaysia/article/malaysia-rates-itself-verygood-in-inaugural-shariah-index\#sthash.9QyWvFx4.dpuf

xix. The Malaysian Family Wellbeing Index, 2011. LPPKN, The Malaysian Family Wellbeing Index. [Online] Available at: http://www.lppkn.gov.my/

xx. The Sun Daily, 2016. Najib to table Syariah Index Report on March 28. [Online] Available at: http://www.thesundaily.my/news/1671034

xxi. The Sun Daily, n.d. The Sun Daily. [Online] Available at: http://www.thesundaily.my/news/1741472 